\title{
Role Playing for Cooperative Skills
}

\author{
Yuli Tri Andini \\ Graduate School \\ Universitas Negeri Yogyakarta \\ Yogyakarta, Indonesia \\ yulitri63@gmail.com
}

\author{
Farida Agus Setiawati \\ Graduate School \\ Universitas Negeri Yogyakarta \\ Yogyakarta, Indonesia \\ farida_as@uny.ac.id
}

\begin{abstract}
Children spend most of their time play with others. When they play, a lot of their ability will improve, and cooperative skills is one of them. To develop cooperative skills, needed the right methods. In this work, we implement role playing method on children age 5-6 years old to improve their cooperative skills. We divide the sample in two groups, experimental group and control group. The results of this work indicate that there are differences in the cooperative skills of children aged 5 to 6 that increase specially used role playing.
\end{abstract}

Keywords-Role playing, Cooperative skills, Learning method

\section{INTRODUCTION}

Developing ability of skills influence by many factors, one of it is learning method. Learning method in early school has many types among other is question and answer method, demonstration, field trip, storytelling, assignment method, project method and role play. In fact, cooperation ability is important to improving because is used to exercise children in their social life that always coexist with others, the essence of being a social being cannot be separated from human life. Therefore, by training children working with it then also can develop basic skills in children's social intelligence. Develop the child in the cooperative skills can be done with certain game form as well as certain game methods, by providing stimulation of the development of children's cooperation skills that will help the child in social activities and get social acceptance attitude when the child can adapt and be have cooperation with his friend. Cooperative ability of children aged 5-6 years old to lowly. It's because teachers rarely used learning method to increase cooperative skills. Teacher always teach to increase intelligent skills, even though cooperation skills and social ability is important too.

One of method can used increase social skills is role playing, because in role playing children learn about rules and what can to do and not [1]. When children form a team and play a scenario. The interaction of the child continuously will nurture the child's closeness or intimacy with other children, so the ability of the child's cooperation will be formed [2][3]. When playing the role of the child process their good experience, and then can affect to developing a social and emotion of children [4].

The stage of playing the child based on the stages of playing Piaget mentions that there are three stages, namely 1) Functional / Play Sensorimotor (Functional
/ sensorimotor play), 2) play symbolic / play drama (Symbolic / dramatic play), 3) play with rules rules) [5]. Any steps to playing social children.

Playing a very close role with the child, Smilansky adds Piaget's stage of play, explaining that children who are 4 years old and school age participate in roleplaying or so-called constructive stages of play. Play the role of dominating the game, and participants use the property equipment, creativity, and imagination, as well as the social interaction necessary to perform this stage of the game [5]. By playing the role of children can learn various things that exist around the child's environment. Piaget, Vygotsky, and Bruner indicate that children will develop representative abilities when playing, role play is an active form of play in which children, through clear behavior and language, relate to matter or situations as if they have other attributes than they really are [6].

In this work, role playing used for cooperative skills for children age 5 to 6 . which distinguishes from previous research is the role play that is used tailored to the theme being studied by the child, so that the goals on aspects of child development can also be realized in addition to the skills of cooperation itself.

\section{ROLE PLAYING}

Role play can be used as one of the learning methods to teach children to patiently wait their turn, get their turn and share [7]. Role play is a challenge for the players because there are a few strict rules to obey; it is open to imagination, new moves and details. The players may want to direct and control the ongoing play but at the same time they have to do so in cooperation with the co-players (other players) [8]. David classifies the four basic elements of cooperation, namely: the mutual interdependence of the child in doing business together, the direct interaction between children in one group, each child has a responsibility to be able to master the taught material, the appropriate use of interpersonal and small group skills, which every child has [9]. Plus, cooperation there is a communication that exists between children [10]. The child who engaged and responds to peers with positive feelings, who is interest to them and whom they highly regard, who can take the lead as well as follow, and who is able to sustain the give and take of peer interaction [11].

Role playing is a symbolic behavior that one thing is to play with fun and as if it is another [2]. Role- 
playing is an action of the mind and not just a behavior when the intention to play the role openly [3]. Playing a role can be a solitary activity, when a child shares his personal fantasy world with a doll, or other miniature or imaginary like his friend. Role play can significantly contribute to cognitive development, physical, emotional and social development [12]. Role playing methods aim to enable the child to interact with others, focusing on developments such as cognitive development, physical development and emotional development [13].

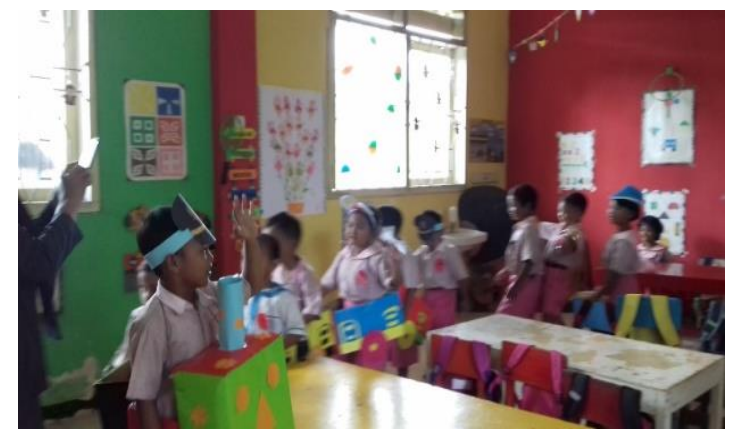

Fig 1. Children role playing about train

Role playing is a symbolic play performed using actual tools or using artificial tools with the use of imagination in children and involves the ability of good cooperation between children who are in the role play group, then the ability of children's cooperation can develop because of the playing a child robber there are elements of cooperation, such as interaction, communication, and form a positive dependence relationship. where they are part of the development of cooperative skills. children are taught to be together in the game. Thus, the flow of role playing goes accordingly, then the child will begin to get used to doing things together without alienating friends, saying that does not hurt like making fun, and the child will start to know each other because of the communication that is intertwined in it. This is what makes the child become more familiar and make the ability of cooperation to grow.

\section{B. Cooperative Skills}

Cooperation allows collaboration in brainstorming or ideas [14]. Cooperation includes various prosocial actions including taking turns, using toys, equipment or activities, fulfilling requests, coordinating actions to achieve goals, accepting other children's ideas, and negotiating in play [15].

At preschool age, the interaction with friends will become more complex, more effective, and subjectively more prominent. The inclusion of children to school makes children spend more time with friends. At this age, the child begins to adapt himself (egocentrically) to a cooperative (co-operative) or videocentric attitude. Sociocentric is willing to pay attention to the needs of others. Cooperation can increase knowledge, performance, and understanding of children in various tasks and contexts [16]. Groupbased cooperation there is mutual motivation among friends, support, assistance, for mutual success, such as mutual responsibility to fight together [17]. One of the goals of international education is to develop individuals who are independent and able to cooperate [18]. So by developing the ability of children's cooperation it will be ready in the face of global competition and realize the goals of international education. Cooperation also enhances collaborative sharing efforts with others [19].

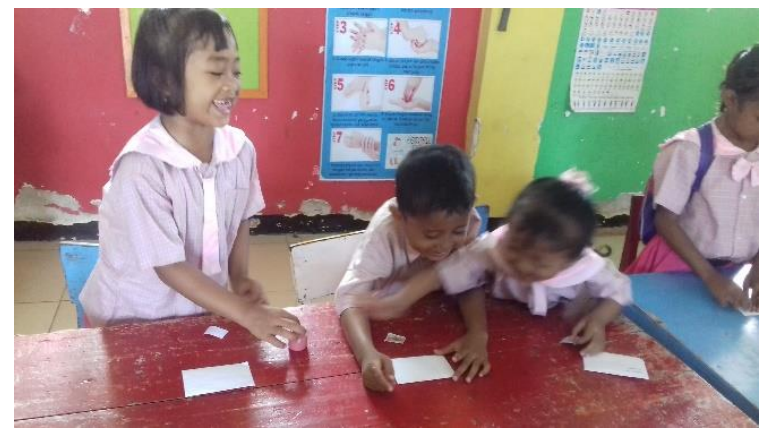

Fig. 2 children help each other when role playing

The purpose of the ability of cooperation include: 1) foster self-confidence of children in groups play together with peers and in social environment, 2) can easily adjust with the environment both family, social and friends. 3) children can learn to understand values, give and receive from an early age as well as children learn to appreciate the giving of others even if children do not like it [9]. Cooperation requires individuals to encourage their own interests or to equate them with others [20]. The goal is a child whose cooperative attitude is good then the children have low aggressivity [21]. That is, by learning to work together then develop cooperation and help children not to behave aggression and association become more familiar with others. Characteristics of cooperation to be used for the instrument in this study are as follows:

- The child has the ability to complete tasks assigned in groups

- Interdependence in doing tasks together.

- Can be actively involved in group games.

- Willing to share with his friends.

- Helping friends who need help

- Mutual respect

- The existence of interaction

- Respond well to anyone offering help.

Doing a job with cooperation will give good results when compared to working alone [22]. Cooperation involves collaboration in exchanging opinions and ideas [14]. By doing the cooperation then the child will have to positive friendship so that children can socialize in the group well. In cooperation the children will have a sense of happiness gained at the time of joint activities or cooperation. 


\section{THE DATA \& METHODOOGY}

\section{A. Data}

Population in this study are 79 children at Kartini's Kindergarten on Banyuwangi Regency on group B. This study used 61 children in group B as sample. Simple random sampling with class lottery technique were used to determine samples. Observation sheets was used as technique and instrument of data collection.

Gregory formula was used in validity test and Cronbach's alpha was used in reliability test. For reliability test used SPSS 16.0 for windows to help calculation reliability Cronbach's alpha.

TABLE 1. VALIDITY OF CONTENT OF GREGORY'S FOR EXPERT JUDGEMENT ON COOPERATIVE SKILLS

\begin{tabular}{|c|c|c|c|}
\hline \multicolumn{2}{|c|}{} & \multicolumn{2}{|c|}{ Expert I } \\
\cline { 3 - 4 } & $\begin{array}{c}\text { Weak } \\
\text { Relevance (1-2) }\end{array}$ & $\begin{array}{c}\text { Strong } \\
\text { Relevance (3-4) }\end{array}$ \\
\hline \multirow{2}{*}{$\begin{array}{c}\text { Expert } \\
\text { II }\end{array}$} & $\begin{array}{c}\text { Weak } \\
\text { Relevance } \\
(1-2)\end{array}$ & A & B \\
\cline { 2 - 4 } & $\begin{array}{c}\text { Strong } \\
\text { Relevance } \\
(3-4)\end{array}$ & C & D \\
\hline
\end{tabular}

Gregory formula was used bellow this:

$$
\mathrm{V}_{\mathrm{i}}=\frac{\mathrm{A}+\mathrm{B}+\mathrm{C}+\mathrm{D}}{\mathrm{D}}
$$

Normality test in this research was conducted by using Kolmogorov Smirnov test on SPSS 16 for windows program. The hypothesis proposed is as follows:

$\mathrm{H}_{0}$ : initial and final distributed data are normal Ha: initial and final data are not normally distributed

Testing normality data using significance level $\alpha$ 0.05 or $95 \%$ confidence level. Criteria for decision of normality test are: (1) if probability greater than 0.05 then $\mathrm{HO}$ is accepted so that the data is declared normal distribution, (2) if the probability is smaller than 0.05 then $\mathrm{Ha}$ is rejected so that data is not normally distributed.

\section{B. Method}

The type of this research is quasi experiment with pretest-posttest non-equivalent control group design. This the experiment uses nonequivalent pretest posttest control group design which divided into pretest, treatment and the last is posttest.

TABLE II. DESIGN PRETEST-POSTEST NON-EQUIVALENT CONTROL GROUP DESIGN.

\begin{tabular}{|l|l|l|l|}
\hline \multicolumn{1}{|c|}{ Group } & \multicolumn{1}{c|}{ Pretest } & \multicolumn{1}{c|}{ Treatment } & Posttest \\
\hline Experiment & $0_{1}$ & $\mathrm{X}_{1}$ & $0_{2}$ \\
\hline Control & $0_{1}$ & $\mathrm{X}_{2}$ & $0_{2}$ \\
\hline
\end{tabular}

We divide the sample in two groups, experimental group and control group. For pretest part, all of children cooperative skills assessed. In treatment phase, role playing given to experimental group (31 student) for a month. On the posttest, all of children's cooperative skills was assessed once again.

Multivariate test with level of significance $(\alpha)<$ 0,05 was used as data analysis technique of hypothesis test. Multivariate test used SPSS 16.0 for windows to help calculation reliability Cronbach's alpha.

This research conducted at Kartini's Kindergarten on Banyuwangi Regency in the academic year 2017/2018. The time of research conducted at the beginning of the even semester of learning approximately one month is around March-April 2018. Includes planning activities research and data retrieval. This research has two variables, one for independent variable is role playing, and dependent variable is cooperative skills. instrument in this study include four aspects of cooperation that is positive dependence, interaction and communication.

\section{THE DATA ASET}

The sample in group B are 61. For experiment used 31 class and 30 for control class. Before treatment, data pretest show that cooperative skills in class experiment and class control is low, after treatment in class of experiment average of score. following details of pretest data in bellow.

TABLE III. DATA PRETEST \& POSTEST COOPERATIVE SKILLS IN CLASS CONTROL AND EXPERIMENT

\begin{tabular}{|l|l|l|l|l|}
\hline \multirow{2}{*}{ Describe } & \multicolumn{2}{|l|}{ Control Group } & \multicolumn{2}{l|}{ Experiment Group } \\
\cline { 2 - 5 } & Pretest & Postest & Pretest & Posttest \\
\hline Average & 14,13 & 14,23 & 17,22 & 29,84 \\
\hline Std & 2,20 & 2,28 & 2,55 & 3,30 \\
\hline Highest Score & 18 & 19 & 24 & 36 \\
\hline Low Score & 10 & 10 & 13 & 22 \\
\hline
\end{tabular}

Normality test in this research was conducted by Kolmogorov Smirnov test on SPSS 16 for windows program this result for normality test Normality test show that the value of sig. test of pretest normality of cooperative ability in experimental group showed significance value in Kolmogorov Simonov table showed $\operatorname{Sig}>\alpha(0,145>0,05)$ and posttest value $(0,200>0,05)$, mean data in normal distributed experiment group, also group control of pretest data on Kolmogorov Simonov table shows Sig value. $>\alpha$ $(0.123>0.05)$ and the posttest data has Sig. $>\alpha(0.197>$ $0.05)$, which means that the data in the pretest control group of cooperative ability are also normally distributed.

Based on exposure of significance value of test of normality of ability of cooperation both in experiment and control class at the time of pretest and posttest is normal distributed. So, the normality in the experimental class and the control class meets the normality requirement which says that, the data is said to be normal if the value of Sig>0.05. 
Multivariant testing techniques (T2 Hotelling) is used to measure the existence of differences in independent variables on several dependent variables simultaneously or simultaneously. Hypothesis testing criterion is $\mathrm{H}_{\mathrm{o}}$ rejected if the resulting (probability) significance is smaller $(<)$ than 0.05 using SPSS 16.0 for windows help. The multivariate test results can be seen in the table below:

\begin{tabular}{|c|c|c|c|c|c|c|}
\hline \multicolumn{2}{|r|}{ Effect } & Value & $\mathbf{F}$ & $\begin{array}{c}\text { Hypoth } \\
\text { esis df }\end{array}$ & $\begin{array}{c}\text { Error } \\
\text { df }\end{array}$ & Sig. \\
\hline \multicolumn{2}{|c|}{ Intercept Pillai's Trace } & .991 & $\begin{array}{r}6.686 \mathrm{E} \\
3^{\mathrm{a}}\end{array}$ & 2.000 & $\begin{array}{r}117.00 \\
0\end{array}$ & .00 \\
\hline & $\begin{array}{l}\text { Wilks' } \\
\text { Lambda }\end{array}$ & .009 & $\begin{array}{r}6.686 \mathrm{E} \\
3^{\mathrm{a}}\end{array}$ & 2.000 & $\begin{array}{r}117.00 \\
0\end{array}$ & .000 \\
\hline & $\begin{array}{c}\text { Hotelling's } \\
\text { Trace }\end{array}$ & $\begin{array}{r}114.28 \\
8\end{array}$ & $\begin{array}{r}6.686 \mathrm{E} \\
3^{\mathrm{a}}\end{array}$ & 2.000 & $\begin{array}{r}117.00 \\
0\end{array}$ & .000 \\
\hline & $\begin{array}{c}\text { Roy's } \\
\text { Largest Root }\end{array}$ & $\begin{array}{r}114.28 \\
8\end{array}$ & $\begin{array}{r}6.686 \mathrm{E} \\
3^{\mathrm{a}}\end{array}$ & 2.000 & $\begin{array}{r}117.00 \\
0\end{array}$ & .000 \\
\hline \multirow[t]{4}{*}{ Prepos } & Pillai's Trace & .701 & $\begin{array}{r}1.369 \mathrm{E} \\
2^{\mathrm{a}}\end{array}$ & 2.000 & $\begin{array}{r}117.00 \\
0\end{array}$ & .000 \\
\hline & $\begin{array}{l}\text { Wilks' } \\
\text { Lambda }\end{array}$ & .299 & $\begin{array}{r}1.369 \mathrm{E} \\
2^{\mathrm{a}}\end{array}$ & 2.000 & $\begin{array}{r}117.00 \\
0\end{array}$ & .000 \\
\hline & $\begin{array}{c}\text { Hotelling's } \\
\text { Trace }\end{array}$ & 2.341 & $\begin{array}{r}1.369 \mathrm{E} \\
2^{\mathrm{a}}\end{array}$ & 2.000 & $\begin{array}{r}117.00 \\
0\end{array}$ & .000 \\
\hline & $\begin{array}{c}\text { Roy's } \\
\text { Largest Root }\end{array}$ & 2.341 & $\begin{array}{r}1.369 \mathrm{E} \\
2^{\mathrm{a}}\end{array}$ & 2.000 & $\begin{array}{r}117.00 \\
0\end{array}$ & .000 \\
\hline \multirow[t]{4}{*}{ class } & Pillai's Trace & .801 & $\begin{array}{r}2.362 \mathrm{E} \\
2^{\mathrm{a}}\end{array}$ & 2.000 & $\begin{array}{r}117.00 \\
0\end{array}$ & .000 \\
\hline & $\begin{array}{l}\text { Wilks' } \\
\text { Lambda }\end{array}$ & .199 & $\begin{array}{r}2.362 \mathrm{E} \\
2^{\mathrm{a}}\end{array}$ & 2.000 & $\begin{array}{r}117.00 \\
0\end{array}$ & .000 \\
\hline & $\begin{array}{l}\text { Hotelling's } \\
\text { Trace }\end{array}$ & 4.037 & $\begin{array}{r}2.362 \mathrm{E} \\
2^{\mathrm{a}}\end{array}$ & 2.000 & $\begin{array}{r}117.00 \\
0\end{array}$ & .000 \\
\hline & $\begin{array}{c}\text { Roy's } \\
\text { Largest Root }\end{array}$ & 4.037 & $\begin{array}{r}2.362 \mathrm{E} \\
2^{\mathrm{a}}\end{array}$ & 2.000 & $\begin{array}{r}117.00 \\
0\end{array}$ & .000 \\
\hline \multirow[t]{4}{*}{$\begin{array}{c}\text { prepos } * \\
\text { class }\end{array}$} & Pillai's Trace & .694 & $\begin{array}{r}1.326 \mathrm{E} \\
2^{\mathrm{a}}\end{array}$ & 2.000 & $\begin{array}{r}117.00 \\
0\end{array}$ & .000 \\
\hline & $\begin{array}{l}\text { Wilks' } \\
\text { Lambda }\end{array}$ & .306 & $\begin{array}{r}1.326 \mathrm{E} \\
2^{\mathrm{a}}\end{array}$ & 2.000 & $\begin{array}{r}117.00 \\
0\end{array}$ & .000 \\
\hline & $\begin{array}{l}\text { Hotelling's } \\
\text { Trace }\end{array}$ & 2.266 & $\begin{array}{r}1.326 \mathrm{E} \\
2^{\mathrm{a}}\end{array}$ & 2.000 & $\begin{array}{r}117.00 \\
0\end{array}$ & .000 \\
\hline & $\begin{array}{c}\text { Roy's } \\
\text { Largest Root }\end{array}$ & 2.266 & $\begin{array}{r}1.326 \mathrm{E} \\
2^{\mathrm{a}}\end{array}$ & 2.000 & $\begin{array}{r}117.00 \\
0\end{array}$ & .000 \\
\hline
\end{tabular}

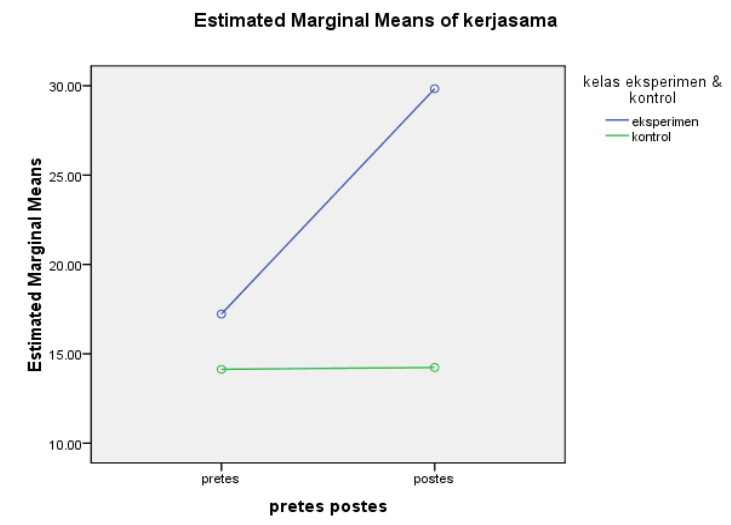

Fig. 3. Differences of result cooperative ability between experiment class and control class.
Based table of multivariate shows the existence of three columns, namely in multivariate test at pretest posttest, difference of experiment class and control class significance, then on pretest post test result with experiment class and control class. The multivariate test used as the reference is the significance value of Hotelling's Trace. The value of significance shows 0.000 in the pretest posttest results that this means the value of $\operatorname{Sig} \alpha<0,05$ so it can be concluded that in the pretest and posttest there are significant differences and influence.

The second column is the experimental class with the control class showing the significance of Hotelling's Trace value is Sig $<\alpha(0,000<0.05)$ which means there is a significant difference between the experimental classes given the role-playing treatment with the non-treated control class. This has proven that role playing method can affect child's cooperative ability as evidenced by the value of multivariate test result as above.

The third column on the test of pretest posttest significance value with the experimental class and control class. The result shows that the Sig $0,000<0,05$ means that there is significant influence on the ability of children's cooperation on pretest and posttest and there is a significant difference between the experimental class given the role-playing treatment and the non-treated control class. Graphic describe that experiment class have increase values than class control.

Based on the three data test results with significant values obtained all showed the value of $\operatorname{Sig}<\alpha$ it can conclude that there is influence role playing on the cooperative skills of children aged 5-6 years in Kartini Kindergarten Banyuwangi Regency.

\section{CONCLUSION}

There is a significant role-playing effect on the improvement of cooperative skills of children aged 56 years in Kartini Kindergarten District Glenmore Banyuwangi District. It is shown from Sig $<\alpha(0,000$ $<0,05)$ that means role playing method influence on child's cooperation ability before and after given treatment to experiment group.

The results of this study may contain the development of broader ideas, if examined also about the implications. Based on the conclusions that have been taken, it is argued that role play affects the ability of cooperation and responsibility of children aged 5-6 years. Role play can be an appropriate method to stimulate aspects of child development as there are values that can be developed, such as interpersonal values, personal values and educational value. Through role play, the child's learning process can be fun and has important value as it can add new 
experiences, develop children's imagination, develop social skills, and develop emotional aspects of the child.

Other researchers are expected to utilize this research as the optimization of efforts to use role playing, so that the cooperative skills children can be more optimal when used right learning method, one of that method is role playing.

\section{REFERENCES}

[1] Selmi et al, Early Childhood curriculum for All Learners: Integrating Play and Literacy Activities. United Kingdom: Sage Publication, Inc., 2015

[2] Lindsey, E. W., Colwell, M. J., Pretend and Physical Play: Links to Preschoolers Affective Social Competence. MerrillPalmer Quarterly July 2013, Vol. 59, No. 3, pp. 330-360: Wayne State University Press, 2013.

[3] Hughes, Children, Play, and Development. University of Wisconsin Madison: Allyn and Bacon, 2010.

[4] Sheridan, S.\& Samuelsson, P., Preschool and Source for Young Children's Learning and Well Being. International Journal of Early Years Education, 21, 2013 pp.2-3, 207-222 DOI: 10.1080/09669760.2013.832948: Routlege.

[5] Dietze, Foundations of Early Childhood Education Learning Environments and Childcare in Canada. Canada: Pearson Prentice Hall, 2006.

[6] Hurlock, Child Development (Perkembangan Anak). (Translate: Meitasari Tjandrasa). Jakarta: Erlangga, 1978.

[7] Bilmes, Beyond Behaviour Management second edition: The Six Life Skills Children Need. United States of America: Redleaf Pers, 2012.

[8] Tykyylainen \& Laakso, Five-year-old girls negotiating pretend play: Proposals with the Finnish particle jooko. Journal of Pragmatics, Elsevier: 42, 2010, pp. 242-256.

[9] Suyanto, Pendidikan Anak Usia Dini. Yogyakarta: Hikayat. 2005, pp. 55-60.

[10] Jurowsky \& Hanze, how to increase the benefits of cooperation: Effects of training in transactive communication on cooperative learning. British Journal of Educational Psychology, 2015, pp. 85, 357-371. The British Psychological Society

[11] Sroufe,Cooper \& DeHart, Child Development Its Nature and Course. Boston: McGraw-Hill Companies, 1996, pp. 120 125.

[12] Lillard, S. A., Lemer, D. A., Hopkins. J. E., Dore, A., Smith, D. E., \& Palmquist, M. C., The Impact of Pretend Play on Children's Development: A Review of the Evidence. American Psychological Association, 2012. 00332909/12/\$12.00 DOI: IO.IO37/aOO29321.

[13] Sheridan, S.\& Samuelsson, P., Preschool and Source for Young Children's Learning and Well Being. International Journal of Early Years Education, 21: 2013, pp. 2-3, 207-222. DOI: 10.1080/09669760.2013.832948: Routlege.

[14] Lazlo, Cooperative Learning in The Kindergarten. Euromentor Journal. Volume IV, 98 No. 3/September: 99, 2013, pp. 99-104

[15] Beaty, Observasi Perkembangan Anak Usia Dini Edisi Ketujuh. Jakarta: PT Fajar Interpratama Mandiri, 2013, pp. 120-121.

[16] Geetha, R, Influence of a Playful, Child-Directed Context on Preschool Children's Peer Cooperation. Vol 58, No.2, Wayne State University, 2012, pp.159-190.

[17] Johnson, W. D., \& Johnson, J. T. "Cooperative Learning." In: The Encyclopedia of Peace Psychology. Blackwell Publishing Ltd. Published by Blackwell Publishing Ltd., 2012, pp. 65-80.

[18] Molenda, C., \& Bhavnagri, N. P. Cooperation Through Movement Education and Children's Literature. Early
Childhood Educ J, 37: 2009, pp. 153-159. DOI 10.1007/s 10643-009-0333-0: Springer.

[19] Benson, B. J. \& Haith, M. M. Social and Emotional Development in Infancy and Early Childhood. USA: Academy Press, 2010.

[20] Tomasello, N., \& Vaish, A. (2013). Origins of Human Cooperation and Morality. Annu. Rev. Psychol, :64, 2013, pp. 231-55. 10.1146/annurev-psych-113011-143812.

[21] Wilkens, E. D. N. Children's shyness, popularity, school liking, cooperative participation, and internalizing problems in the early school years. Early Childhood Research Quarterly, :29, 2014, pp. 85-94.

[22] Eliasa, I. E. Increasing Values of Teamwork and Responsibility of The Students Through Games: Integrating Education Character in Lectures. Procedia - Social and Behavioral Sciences :123, 2014, pp. 196 - 203. Journal Elsevier 